ADAM ŚWIEŻYŃSKI

\title{
Sprawozdanie z konferencji naukowej Wokół poszukiwania życia w kosmosie Instytut Filozofii UKSW, Warszawa, 16 grudnia 2015 r.
}

16 grudnia 2015 roku w budynku Instytutu Filozofii UKSW w Warszawie odbyła się konferencja naukowa pt. Wokót poszukiwania życia w kosmosie, zorganizowana przez pracowników Sekcji Filozofii Przyrody UKSW. Jednym z powodów jej zorganizowania była, przypadająca $\mathrm{w}$ dniu odbywania się konferencji, 20. rocznica śmierci księdza profesora Szczepana W. Ślagi (19341995), prodziekana Wydziału Filozofii Chrześcijańskiej Akademii Teologii Katolickiej w Warszawie (obecnie UKSW) i współtwórcy specjalności filozofii przyrody na tym Wydziale. Ksiądz Profesor żywo interesował się problemem pochodzenia życia, w szczególności hipotezami jego pozaziemskich początków. Tej problematyce poświęcił wiele prac, w których próbował ocenić wartość tych hipotez z punktu widzenia filozofa.

Innym motywem, który skłonił pracowników Sekcji Filozofii Przyrody do podjęcia problematyki poszukiwania życia w kosmosie w ramach zorganizowanej konferencji, są realizowane aktualnie badania naukowe w tym zakresie, m.in. zakończenie w 2014 roku jednego z etapów misji „Rosetta” (na komecie 67/P Czuriumow-Gierasimienko wylądował Philae - lądownik Europejskiej Agencji Kosmicznej) i wynikające z nich ustalenia. Pytanie o powstanie życia i rozpatrywanie możliwości jego pozaziemskiego pochodzenia od zawsze nurtowało ludzi, także ze względu na kwestię ich własnych początków. Współcześnie coraz częściej wskazuje się nie tylko na możliwość istnienia życia poza Ziemią, ale także na jego pozaziemską genezę. Konstruując modele abiogenezy, badacze uwzględniają więc w różnym zakresie jej kosmiczny etap, który według niektórych doprowadził do powstania życia nie tylko na naszej planecie. Jednym z celów konferencji było pokazanie, że początek życia, ze względu na rozmaitość wskazywanych przyczyn, jest zagadnieniem interdyscyplinarnym. „Wprawdzie samo rozumienie początku czy przyczyny powstania życia jest nieco inne na płaszczyźnie nauk przyrodniczych, filozofii i teologii, lecz 
te różne punkty widzenia nie muszą się wykluczać, a mogą dać pogłębione spojrzenie na istotę życia. Każda próba zbadania początków życia na Ziemi, również wskazująca na jego kosmiczne pochodzenie, ma też znaczenie dla określenia naszego miejsca w świecie, a także celu ludzkiego życia” (A. Lemańska, Zaproszenia do udziatu w konferencji). Ze względu na taki charakter zaproponowanej problematyki z zaproszenia do udziału w konferencji skorzystali zarówno przyrodnicy, jak i filozofowie, teologowie oraz literaturoznawcy. Uczestnicy konferencji wygłaszający referaty reprezentowali ośrodki naukowe z Kielc, Krakowa, Lublina, Olsztyna, Poznania, Szczecina i Warszawy.

Konferencję otworzyła dziekan Wydziału Filozofii Chrześcijańskiej UKSW w Warszawie, prof. dr hab. Anna Latawiec. Powitała uczestników konferencji oraz wyraziła radość z powodu jej zorganizowania, uznając doniosłość podjętej tematyki. Nawiązała także do postaci ks. prof. Sz. W. Ślagi, przypominając jego sylwetkę i osiągnięcia naukowe.

W dalszej kolejności przystąpiono do wysłuchania referatów zgrupowanych w trzech częściach tematycznych. W pierwszym wystąpieniu prof. dr hab. Ewa Szuszkiewicz z Polskiego Centrum Astrobiologii CASA* oraz Wydziału Matematyczno-Fizycznego Uniwersytetu Szczecińskiego zaprezentowała temat: Nasze miejsce we Wszechświecie: kim jesteśmy i dokqd zmierzamy. Prelegentka, odwołując się do obecnych ustaleń naukowych z zakresu fizyki, astronomii i kosmologii, starała się odpowiedzieć na zasadnicze pytania: Skąd wzięło się życie i jak następowała jego ewolucja? Jaka jest przyszłość życia na Ziemi i gdziekolwiek indziej? Czy jesteśmy sami we Wszechświecie? E. Szuszkiewicz zauważyła, że pytania te ludzkość zadawała sobie od zawsze, a współcześnie zadajemy je sobie również my, ludzie żyjący tu i teraz, ale bogatsi o zrozumienie podstawowych praw natury. Udało nam się poznać strukturę materii oraz sposoby, w jaki ciała materialne oddziałują ze sobą. Odkryliśmy nowe planety, nowe gwiazdy oraz inne obiekty znajdujące się w przestrzeni kosmicznej. Poznaliśmy budowę i funkcjonowanie organizmów żywych. Nauczyliśmy się wykrywać i leczyć choroby, dzięki czemu żyjemy dłużej i lepiej. Rozwinęliśmy także technologie, które pozwalają nam na poznawanie odległych obiektów we Wszechświecie oraz struktur mikroświata. Następnie prelegentka zauważyła, że dalszy postęp w poszukiwaniu odpowiedzi na pytania o pochodzenie 
życia, jego ewolucję i rozprzestrzenienie się we Wszechświecie będzie wymagał połączenia wiedzy i metod działania specjalistów w wielu dyscyplinach w jedną spójną całość. Konieczna jest więc stała i pogłębiona integracja nauk. Bardzo młoda, w porównaniu do astronomii, astrobiologia podjęła się właśnie tego zadania. E. Szuszkiewicz przedstawiła stan obecny poszukiwań życia w kosmosie oraz najważniejsze osiągnięcia astrobiologii. Naszkicowała także kierunki dalszych badań i ich oczekiwane wyniki.

W kolejnym wystąpieniu, zatytułowanym Miejsce cztowieka w kosmosie: dane empiryczne i perspektywa astronautyczna, prof. dr hab. Jan F. Terelak z Instytutu Psychologii UKSW w Warszawie, reprezentujący także Komitet Badań Kosmicznych i Satelitarnych PAN, przedstawił wielorakie związki intelektualne i emocjonalne człowieka $\mathrm{z}$ kosmosem, ujawniające się, $\mathrm{z}$ jednej strony, w rozwoju kosmologii i astronomii, a z drugiej - w ikonografii religijnej i literaturze pięknej oraz prozie naukowo-fantastycznej (science-fiction). J. Terelak zauważył, że zebrane przez tysiąclecia dane naukowe i mity na temat kosmosu były i są podstawą budowania narzędzi (np. teleskopy, satelity, sondy kosmiczne), przydatnych do ich weryfikacji. Jednakże dopiero w XX wieku człowiek postanowił osobiście krok po kroku, niejako fizycznie „dotknąc” kosmosu. Kroki te to rozwój narzędzi transportu pozaziemskiego, m.in. takich jak: baloniarstwo i lotnictwo stratosferyczne, statki kosmiczne (orbitalne i międzyplanetarne) oraz stacje kosmiczne. Działalność ta nazwana w literaturze przedmiotu astronautyką, wzbudziła nowe nadzieje na eksploracje kosmosu, ale także wygenerowała nowe mity, wśród nich mit o nieograniczonym podboju kosmosu przez człowieka. J. Terelak omówił postępy współczesnej astronautyki ze szczególnym uwzględnieniem barier medycznych i psychologicznych uniemożliwiających długoterminowe przebywanie człowieka Kosmosie. W konkluzji swojego wystąpienia prelegent sceptycznie odniósł się do roztaczanych współcześnie wizji szybkiego i skutecznego podboju przestrzeni kosmicznej przez człowieka (np. program „Mars One”). Wskazał na wiele barier natury fizykalnej, biologicznej i psychologicznej, których przekroczenie będzie wymagało nie tylko odpowiedniego postępu technicznego, ale także stopniowej i powolnej adaptacji ludzkiej psychiki do nowych warunków kosmicznego bytowania. W opinii J. Terelaka niektóre ze wspomnianych barier wydają się 
z dzisiejszej perspektywy niemożliwie do przekroczenia przez człowieka ze względu na jego naturalne wyposażenie i związane z nim ograniczenia.

Następnym prelegentem był dr Jacek Poznański z Akademii „Ignatianum” w Krakowie. W wystąpieniu: Ziemska nauka, a możliwości komunikacji z cywilizacja pozaziemska: C. Sagan, N. Rescher, A. Kukla autor nawiązał do postaci trzech badaczy, którzy w różny sposób podejmowali problematykę istnienia cywilizacji pozaziemskich i możliwości nawiązania kontaktu z nimi przez człowieka. W latach siedemdziesiątych XX wieku Carl Sagan i inni przedstawiciele programu mającego na celu nawiązanie komunikacji z pozaziemską cywilizacją, twierdzili optymistycznie, że choćby wszystko inne radykalnie różniło inteligentne istoty pozaziemskie od ludzi, to jednak będą one posiadały jeden wspólny temat rozmowy: prawa nauki i matematyki. Według C. Sagana te prawa są takie same wszędzie we wszechświecie i niezmiennicze wobec uwarunkowań biologicznych, środowiskowych oraz kulturowych. Sformułował on w ten sposób argument nazywany później The one world - one science argument - jeśli istnieje jeden wszechświat, to istnieje jedna dla całego wszechświata nauka. Obszerną argumentację przeciw temu podejściu przedstawił Nicholas Rescher, wskazując na istotne trudności w stosowaniu terminu 'nauka' poza kontekstem ziemskim, czy porównywaniu nauki ludzkiej z „nauką” pozaziemską. Nasza nauka bowiem odzwierciedla charakterystyczne ludzkie ograniczenia. Można całkiem zasadnie przypuszczać, że teorie nauk przyrodniczych nie są uniwersalnie ważne i uzasadnione dla wszystkich racjonalnych inteligencji. N. Rescher dochodzi do wniosku, że ,jeśli obce cywilizacje zamieszkują obce światy myślowe, to ten brak intelektualnej wspólnoty może dobrze wyjaśnić brak fizycznej komunikacji”. Jego rozważania wzmocnił André Kukla, argumentując za tezą, że nawet jeśli założymy, iż istnieje jeden świat (jego prawa i materia, z której jest zbudowany są wszędzie te same; wszędzie działa kosmiczna ewolucja), i nawet jeśli fakt ten prowadzi do jednej nauki, to i tak nic to nie mówi o możliwości bądź niemożliwości komunikacji z istotami pozaziemskimi. W swoim referacie J. Poznański poddał argumentację wymienionych autorów różnorodnej krytyce przede wszystkim z punktu widzenia filozofii nauki oraz ukazał problemy wynikające ze zbyt 
optymistycznego i jednostronnego rozpatrywania kwestii możliwości istnienia i nawiązania komunikacji z cywilizacjami pozaziemskimi.

Po przerwie pierwszym prelegentem był dr hab. Adam Świeżyński z Instytut Filozofii UKSW. W wystąpieniu zatytułowanym: Od idei samorództwa do teorii abiogenezy kosmicznej. Analiza pogladów na temat powstania życia w kontekście idei kosmicznego pochodzenia życia prelegent podjął zagadnienie wielości teorii wyjaśniających problem powstania życia oraz ich systematyzacji. We współczesnej nauce, w drugiej połowie XX wieku, pojawiły się nowe dziedziny, których przedmiotem zainteresowania są powstanie i istnienie życia poza Ziemią. Najważniejsze z nich to: kosmochemia; astrochemia; egzobiologia; bioastronomia; astrobiologia. Wszystkie te dziedziny nawiązują, choć w różny sposób, do idei kosmicznego (pozaziemskiego) pochodzenia i istnienia życia. $Z$ kolei koncepcją o charakterze filozoficznym, dotyczącą kosmicznego istnienia życia, jest idea odwieczności życia, w której wyrażony został pogląd, że życie jest tak stare jak wszelka istniejąca materia, z której zbudowany jest wszechświat. Idea panspermii, czyli przekonanie o możliwości i faktycznym rozprzestrzenianiu się życia w kosmosie, wraz ideą odwieczności życia, była jednym ze sposobów wyjaśniania pochodzenia życia na Ziemi. Równolegle z nią istniał pogląd o samorzutnym, spontanicznym i nagłym przekształcaniu się materii nieożywionej w materię ożywioną, czyli idea samorództwa (tzw. „naiwnego”). Pierwotne (pierwsze) samorództwo miało wyjaśniać fakt pojawienia się życia na Ziemi. A Świeżyński zauważył, że zarysowana wielość poglądów na temat pochodzenia życia we wszechświecie wymaga uporządkowania i wskazania zależności istniejących między rozmaitymi ideami, a współczesnymi ustaleniami o charakterze empirycznym i związanymi z nimi teoriami naukowymi. W szczególności warto prześledzić rozwój idei kosmicznego pochodzenia życia oraz wskazać na czynniki, które zadecydowały o ukształtowaniu się współczesnej teorii abiogenezy kosmicznej. W wystąpieniu autor uzasadniał tezę, że pojawienie się tych teorii było możliwe przede wszystkim dzięki uprzedniemu powstaniu teorii abiogenezy ziemskiej, a więc pośrednio także dzięki filozoficznej idei samorództwa ziemskiego przekształconej w ideę samoorganizacji materii zgodnie $\mathrm{z}$ ustaleniami o charakterze naukowym (empirycznym) pod wpływem teorii ewolucji fizyko-chemicznej. 
Natomiast idea kosmicznego pochodzenia życia (idea panspermii), choć dotyczy zagadnienia istnienia życia poza Ziemią, nie wpłynęła na pojawienie się teorii abiogenezy kosmicznej, lecz została dzięki niej odrodzona w postaci różnych odmian neopanspermii (np. panspermia międzygwiezdna, panspermia kometarna, panspermia międzyplanetarna) jako wyjaśnienie pochodzenia życia na Ziemi alternatywne wobec abiogenezy ziemskiej. Stało się tak, gdyż idea panspermii nie dotyczy wprost zagadnienia powstania życia, lecz jego istnienia poza Ziemią (i rozprzestrzenienia się we wszechświecie). Nie pojawiła się zaś w historii myśli ludzkiej idea stanowiąca odpowiednik idei samorództwa ziemskiego, czyli idea samorództwa kosmicznego. Zdaniem A. Świeżyńskiego należy zauważyć, że w wielu opracowaniach historycznych idea panspermii jest ściśle łączona ze współczesnymi teoriami abiogenezy kosmicznej jako ich „nienaukowa poprzedniczka”, podczas gdy powinna być uznana jedynie za „prekursorkę” neopanspermii. Wnioskiem natury ogólnej, uzyskanym z zaprezentowanej przez autora analizy, jest wyróżnienie dwóch składowych obecnych we współczesnych naukowych teoriach na temat powstania życia: składowej ideowej i składowej empirycznej.

Kolejnym mówcą był dr hab. Wiesław Dyk z Wydziału Teologicznego Uniwersytetu Szczecińskiego. Zaprezentował on temat Świat tioestrów. Rola tioestrów w procesie genezy życia. W swoim wystąpieniu odwołał się do ustaleń belgijskiego noblisty, Christiana de Duve, który uznał, że procesy chemiczne oparte na tioestrach mogą być podstawą genezy życia nie tylko na Ziemi, ale także - przy sprzyjających warunkach planetarnych - w kosmosie. Ch. de Duve wymienił siedem „filarów życia”, które muszą być spełnione na każdym etapie jego istnienia, tzn. konieczne są one do zaistnienia systemów ożywionych i utrzymania ich w powstaniu, istnieniu oraz rozwoju: 1) wytwarzanie swoich części z materiałów dostępnych we własnym otoczeniu, 2) czerpanie energii ze swego środowiska i przetwarzanie jej w różne formy pracy w celu utrzymania się przy życiu, 3) musi istnieć proces katalizowania wielu chemicznych reakcji koniecznych do wspierania dynamiki systemów żywych, 4) kierowanie procesów biosyntetycznych oraz innych reakcji chemicznych w taki sposób, aby zapewnić sobie właściwą reprodukcję, 5) konieczne jest względne odizolowanie się od otoczenia, aby utrzymać ścisłą kontrolę nad wymianą energii 
i materii ze środowiskiem, 6) regulowanie swej aktywności w celu zachowania dynamicznej organizacji mimo zmienności środowiskowej, 7) multiplikacja (rozmnażanie). Wymienione „filary” wskazują na to, że świat RNA poprzedza czasowo istnienie współcześnie znanych struktur białkowych. Powstały świat RNA-proteinopodobny zainicjował protometabolizm. Przyjęcie tego pierwszego etapu protobiologicznego odsłania kolejne możliwe etapy ewolucji życia: synteza polinukleoidów; rozwój i replikacja RNA; zależna od RNA synteza peptydów; rozwój mechanizmu translacji; wyłonienie się enzymów proteinowych. Istotną rolę wyłonienia się procesów deterministycznych kierujących ku tworzeniu się struktur i funkcji systemów ożywionym Ch. de Duve przyznaje tioestrom. Znaczenie tioestrów w protobiotycznych warunkach uzasadnia on, odwołując się do ich roli w metabolizmie współcześnie istniejących organizmów żywych. Belgijski uczony dostrzegł także duże znaczenie katalizatorów w procesach przebiegających od protometabolizmu do metabolizmu. Nie jest to tylko teoretyczne założenie, bo i we współczesnych organizmach katalizatory także występują. Skoro tak, to katalizatory musiały występować od początku chemicznych przemian w prebiotycznym świecie i odegrały istotną rolę w genezie życia. Fakt powstania cząsteczek chemicznych w łączności z odpowiednimi katalizatorami umożliwia ukazanie, że od początku istniał deterministyczny proces powstawania i przetwarzania się materii $\mathrm{w}$ coraz to bardziej istotne cząsteczki konieczne abiotycznie. Idąc za propozycją Güntera Wächtershäustera, Ch. de Duve przyjmuje, że ewolucja życia przebiegała w sposób spontaniczny, ale zgodnie z prawami przyrody, również z zasadami termodynamiki. Proces tworzenia się coraz bardziej złożonych związków chemicznych przedstawia w tzw. czterech światach: 1) prebiotyczny, 2) tioestrów, 3) RNA, 4) DNA. Zgodnie z modelem świata tioestrów, życie rozpoczęło się w wulkanicznym, bogatym w siarczan otoczeniu, bogato zaopatrzonym w abiotycznie powstałe tiole i kwasy organiczne różnego rodzaju, włączając aminokwasy i hydroksykwasy.

Trzecim prelegentem w drugiej części konferencji był dr Andrzej Zykubek z Katedry Filozofii Nauk Przyrodniczych Katolickiego Uniwersytetu Lubelskiego Jana Pawła II. W wystąpieniu zatytułowanym Astrobydrobiologia autor zauważył, że obecność wody w stanie ciekłym uważana jest za jeden 
z podstawowych czynników powstania i ewolucji życia, a tym samym wyznaczników tzw. strefy habitualnej (ekosfery). W związku z tym praktyka badań astrobiologicznych koncentruje się przede wszystkim na priorytetowej ocenie tego biowskaźnika, tzn. czy na danej planecie lub księżycu może (lub mogła) występować (przynajmniej okresowo) woda w stanie ciekłym. Na tej podstawie w literaturze przedmiotu w Układzie Słonecznym wyróżnia się cztery klasy obiektów kosmicznych jako potencjalnych środowisk życia: 1) Ziemia, 2) Mars, Wenus, 3) Europa, 4) Enceladus, Ganymedes, Callisto, Tytan, Uran, Neptun. Podobną klasyfikację stosuje się dla kosmicznych obiektów spoza Układu Słonecznego. W przedstawionym kontekście w dalszej części wystąpienia A. Zykubek zajął się odpowiedzią na następujące pytania: Czy słuszne jest założenie o priorytetowej roli tego „wodnego biowskaźnika”? Czy z punktu widzenia powstania i ewolucji życia ważne są źródła pochodzenia wody (np. auto- lub allogeniczne hipotezy pochodzenia wody na Ziemi)? Kiedy na Ziemi lub innych obiektach kosmicznych pojawiły się „wodne” warunki do powstania życia? Czy możliwe jest życie bez wody, a jeśli tak, w jakich warunkach może zrealizować się tzw. anhydrobioza? Czy jesteśmy świadkami narodzin nowej dyscypliny naukowej o nazwie: astrohydrobiologia?

Ostatnim prelegentem w tej części konferencji był dr Jerzy Rąpała z Wyższego Seminarium Duchownego Zakonu Braci Mniejszych we Wronkach (Sekcja Wydziału Teologicznego UAM w Poznaniu). Zaprezentował on temat: "Hipoteza podobieństwa" a poszukiwanie życia w kosmosie. Próba analizy krytycz$n e j$. Nawiązując do poglądów Szczepana Ślagi, zauważył, że wspomniany autor, analizując podstawowe założenia teorii abiogenezy, wyróżnił wśród nich tzw. „hipotezę podobieństwa”. Głosi ona, iż pierwsze istoty żywe, które pojawiły się na Ziemi, były podobne do występujących współcześnie pod względem struktury chemicznej i metabolizmu. Zasada ta pojawia się również na terenie astrobiologii, kierując badania ku poszukiwaniu życia podobnego do ziemskiego (tzn. opartego na związkach węgla, posiadającego budowę komórkową, zawierającego wodę jako główny rozpuszczalnik). J. Rąpała zaprezentował stanowiska krytyczne wobec wspomnianego założenia, zawarte w koncepcjach N. W. Piriego, W. Sedlaka i A. G. Cairns-Smitha. Analizie poddał dwa podstawowe sposoby uzasadniania „zasady” przez jej zwolenników, tzn. argument 
z jedności biochemii oraz eksperymentów modelowych. Stwierdził także, iż tezy zawarte we wspomnianych koncepcjach biogenezy mogą stanowić ważny głos w dyskusji nad charakterem misji badawczych poszukujących śladów życia w kosmosie. Odrzucenie „hipotezy podobieństwa” skutkuje bowiem poszerzeniem zakresu badań i zwraca uwagę naukowców na tzw. „alternatywne formy i środowiska życia”.

W trzeciej części konferencji jako pierwszy zabrał głos dr hab. Grzegorz Bugajak z Instytutu Filozofii UKSW w Warszawie. Przedstawił temat: Kosmiczne poczatki życia w świetle hipotezy niedookreśloności celu stworzenia. $\mathrm{Na}$ wstępie prelegent zauważył, że dla teologicznej refleksji na temat miejsca człowieka w świecie, trzy „wydarzenia” - z punktu widzenia dogmatu o stworzeniu - wydają się mieć istotne znaczenie: stworzenie świata, stworzenie życia i powołanie do istnienia człowieka. W nurcie zwanym kreacjonizmem ewolucyjnym uznaje się zwykle, że o ile rozwój świata zachodzi mocą praw natury, nadanych przez Boga, lecz działających samodzielnie i będących przedmiotem badań naukowych, to te trzy „momenty” w historii świata wymagają szczególnej interwencji Stworzyciela. W sukurs takim poglądom przychodzi analiza filozoficzna, która - zakładając istotną odrębność życia od tego, co nieożywione, i przyjmując zasadę racji dostatecznej - wiedzie do wniosku, że powstanie życia, choć „przygotowane” działaniem czynników naturalnych, wymaga dopełnienia przyczynowego ze strony nadnaturalnej Przyczyny Pierwszej. Wyniki badań naukowych, uprawdopodobniające dzisiaj możliwość kosmicznego pochodzenia życia ziemskiego, stają się dla tych filozoficzno-teologicznych poglądów kłopotliwe. Można, co prawda, utrzymywać, że życie - niezależnie od tego czy powstało na Ziemi, czy też jest wynikiem „kosmicznego zasiewu” - nadal wymaga specjalnego aktu stworzenia, jednak przyjęcie jego kosmicznego pochodzenia prowadzi do pytań o „ekonomię” tego aktu: skoro ostatecznym zamiarem Boga było powołanie do istnienia człowieka, a stworzenie życia jest tylko jednym z etapów realizacji tego stwórczego planu, to trudno znaleźć uzasadnienie dla jego powstania poza główną sceną dramatu Stworzenia. G. Bugajak stwierdził, że hipoteza niedookreśloności celu stworzenia pozwala na usunięcie tego dylematu. Postuluje ona ściśle teologiczne - a nie biologiczne - rozumienie człowieka: człowiek, to istota 
powołana do szczególnej relacji z Bogiem. To, że - patrząc od strony przyczyn naturalnych - istota taka powstała na planecie Ziemi i przybrała postać biologicznego gatunku Homo sapiens, jest rzeczą drugorzędną. Jeśli ostatecznym stwórczym celem Boga jest powołanie do istnienia istoty zdolnej do poznania Go i nawiązania z Nim szczególnej relacji, to ani fizyczny kształt takiej istoty, ani jej „miejsce urodzenia” nie mają większego znaczenia. Podobnie - życie, o ile faktycznie jest czymś istotnie odrębnym od tego, co nieożywione, mogło powstać w dowolnym czasie i miejscu stworzonego świata, jako jeden z etapów, prowadzących do - niedookreślonego w fizycznych szczegółach - ostatecznego celu stworzenia.

Kolejnym prelegentem był dr hab. Jacek Rodzeń z Uniwersytetu Jana Kochanowskiego w Kielcach, który zaprezentował wystąpienie: „Mieszkańcy grwiazd" wedtug Karla Rabnera. Autor najpierw przypomniał postać i dokonania Karla Rahnera oraz przedstawił jego poglądy na temat teologicznego znaczenia ewentualnego istnienia istot inteligentnych poza Ziemią. W opinii prelegenta K. Rahner był nie tylko wybitnym teologiem (i filozofem), ale należał również do tych nielicznych współczesnych teologów, którzy w swoich dziełach podjęli niemal wszystkie ważne, (pozornie) mniej ważne, i te zwykle tylko lekko dostrzegalne kwestie, będące jednak przedmiotem zainteresowania chrześcijan od 2000 lat. Jedną z takich niekoniecznie kluczowych kwestii, a przynajmniej niepodejmowanych przez większość teologów chrześcijańskich, jest problem możliwego istnienia innych, pozaziemskich istot (podmiotowo) rozumnych. K. Rahner analizował ten problem jako teolog, zarazem dysponując dostateczną aktualną dla niego wiedzą (lata 60. i 70. XX wieku) i głęboką świadomością filozoficzno-metodologiczną dotyczącą możliwości w tym względzie nauk przyrodniczych. Zgodnie z przekonaniem wielu teologicznych poprzedników (w tym Tomasza z Akwinu), doktryna chrześcijańska według K. Rahnera nie wyklucza możliwości istnienia inteligentnych istot poza Ziemią (w sensie czasoprzestrzennym). Jednocześnie niemiecki teolog stwierdził, że choć boska inkarnacja w innych częściach kosmosu jest możliwa do pomyślenia, należy odkrywać znaczenie uniwersalistyczno-kosmicznego wymiaru wcielenia Boga w Jezusie Chrystusie na Ziemi, także dla możliwie istniejących rozumnych istot pozaziemskich. Według K. Rahnera sensem i celem świata 
jest swoiste „spotkanie" samoudzielającego się Boga (przez objawienie i łaskę) $\mathrm{z}$ autotranscendencją kosmosu, w tym nie tylko istot ludzkich, ale także innych istot rozumnych. Oczywiście, jak zastrzegł sam omawiany autor, o ile te ostatnie faktycznie istnieją.

Kolejną prelegentką ostatniej części konferencji była mgr Jurata Bogna Serafińska. W wystąpieniu zatytułowanym Starożytne podróże grwiezdne zwróciła uwagę na fakt, że w literaturze starożytnej istnieje wiele wzmianek mogących świadczyć o istnieniu życia w kosmosie. Pozornie wydaje się, że to osiągnięcia XX i XXI wieku skłoniły ludzi do pytań o możliwość podróży międzygwiezdnych. Tymczasem ten temat został potraktowany z całą powagą w utworach literackich i świętych księgach, które powstały u zarania dziejów ludzkości (Epos o Gilgameszu, Iliada i Odyseja Homera, Siakuntala Kalidasa, traktaty Inków, Tora i niektóre apokryfy - na przykład Ksiegga Henocha). Autorka podkreśliła, że w apokryficznej Księdze Henocha znajdujemy opis mówiący o sposobie latania na duże odległości w samolotach i w statkach kosmicznych oraz na mniejsze odległości za pomocą skrzydeł (być może rodzaju lotni). Z kolei w sumeryjskim Eposie o Gilgameszu bogowie byli nazywani dosłownie „Szlachetni z Rakiet”. Najmłodszy syn boga Enlila - bóg gór, burzy i piorunów - był władcą obu Ameryk. Zastanawiającym faktem jest, że wysoko w Andach istniała świątynia podobna do tej, którą opisał prorok Ezechiel. Jeden z Tekstów Piramid z papirusu ANI (Księgi Umartych) przedstawia zmarłego faraona w trakcie przygotowań do podróży. Niedaleko faraona znajduje się pojazd o kształcie nowoczesnej rakiety kosmicznej. W dziełach Homera bogowie olimpijscy przemieszczają się błyskawicznie, w zależności od swoich potrzeb lub kaprysów, dysponują „boskimi sandałami” z napędem umożliwiającym pokonywanie wielkich odległości w krótkim czasie. W dramacie Siakuntala Kalidasa - król Duszjanta, mknie na wozie przez kosmiczne przestworza. Ludzie w różnych okresach czasu widywali dziwne obiekty latające. Nazywali je różnie: Hebrajczycy - rydwanami, Izmaelici - latającymi dywanami, Egipcjanie - łodziami niebios, Chińczycy - smokami. Obecnie mówimy o takich obiektach: UFO. Jeśli możliwe byłyby podróże międzygwiezdne, to tym samym życie mogłoby się przenosić w kosmosie. W 2015 roku naukowcy odkryli odległą planetę (Kepler-452b), którą ze względu na jej charakterystykę nazwali „drugą Ziemią”. 
Jest ona nieco większa od naszej Ziemi, jej rok słoneczny trwa 385 dni. J.B. Serafińska wyraziła pogląd, że ponieważ badania naukowe innych planet nadal trwają, to być może okaże się, że starożytni nieświadomi tego zapisywali fakty, a nie zwykłą fantazję na temat życia, które przybyło z kosmosu.

Ostatnim prelegentem w czasie konferencji był dr Jacek Sobota z Instytutu Filozofii Uniwersytetu Warmińsko-Mazurskiego w Olsztynie. Przedstawił on temat: Literackie wizje życia rozumnego w kosmosie i ich konsekwencje metafzyczne, epistemologiczne i aksjologiczne. Autor zauważył najpierw, że literatura fantastyczno-naukowa od dekad kreśli wizje życia rozumnego istniejącego na innych planetach. W przeważającej większości jest to literatura awanturnicza, pozbawiona wartości intelektualnych. Są jednak autorzy (tacy jak Stanisław Lem, Jacek Dukaj, Philip K. Dick, bracia Arkadij i Boris Strugaccy), którzy podejmują tematykę obcości w kontekście rozważań jej filozoficznych konsekwencji. Między innymi pojawia się pytanie, czy możliwe jest porozumienie $\mathrm{z}$ intelektem rozwiniętym w skrajnie różnym od ludzkiego środowisku, wyposażonym być może w odmienną percepcję, sposoby odbioru rzeczywistości (zagadnienia epistemologiczne). Najznakomitszą egzemplifikacją problemu jest, zdaniem prelegenta, powieść Stanisława Lema Solaris, gdzie ludzkość próbuje komunikować się z gigantycznym oceanem plazmy, a więc istotą skrajnie od ludzkości różną. Inny problem sygnalizują bracia Strugaccy w książce zatytułowanej Piknik na skraju drogi - tytuł jest metaforą opisującą różnicę potencjałów kulturowych między obcą cywilizacją (która być może urządza sobie „przerwę w podróży”, nie dostrzegając nawet istnienia ludzkości) a Homo sapiens. Innymi ważnymi zagadnieniami są: konsekwencje metafizyczno-teologiczne wynikające z kontaktu człowieka (ludzkości) z obcymi cywilizacjami (np. koncepcja „kalekiego boga” w twórczości S. Lema); problem „protezowania metafizyki” w literaturze fantastycznej (czyli zastępowania cudowności technologią, Boga - figurą wszechmocnego technologicznie obcego); wpływ istnienia obcych cywilizacji na zmianę (transfer?) naszego systemu wartości. Obecność tych zagadnień we współczesnej literaturze świadczy o tym, że problem istnienia życia pozaziemskiego nie jest jedynie domeną naukowców, lecz kształtuje także świadomość wielu twórców szeroko rozumianej kultury i sztuki i pobudza ich do zmierzenia się z nim m.in. na gruncie literackim. 
Podsumowania całości konferencji dokonała prof. dr hab. Anna Lemańska. Dziękując uczestnikom konferencji, wyraziła opinię, że wielość perspektyw, w których może być ujmowany problem pochodzenia i istnienia życia w kosmosie, stwarza możliwość wszechstronnego i interesującego rozpatrywania tej tematyki. To z kolei powoduje, że poszukiwanie życia w kosmosie staje się nie tylko przedmiotem zainteresowania przedstawicieli nauk przyrodniczych, ale także przedmiotem namysłu filozofów, teologów oraz twórców kultury i sztuki, którzy uznają je za twórcze i ważne dla współczesnego człowieka.

ADAM ŚWIEŻYŃSKI

a.swiezynski@uksw.edu.pl

Uniwersytet Kardynała Stefana Wyszyńskiego w Warszawie, Instytut Filozofii

Wóycickiego 1/3, 01-938 Warszawa

DOI 10.21697/spch.2016.52.1.41 